\title{
PLEURAL ENDOMETRIOSIS: BLOODY PLEURAL EFFUSION IN A 28-YEAR-OLD FEMALE WITH PRIMARY INFERTILITY (CASE REPORT)
}

\author{
S. Saheer, A. Paul, P. James, R. Palak \\ CHRISTIAN MEDICAL COLLEGE AND HOSPITAL, TAMIL NADU, INDIA
}

Background. Endometriosis is defined as presence of endometrial glands outside the uterine cavity and it most commonly involves the structures within the pelvic cavity. Thoracic endometriosis syndrome usually presents as pneumothorax, hemoptysis, hemothorax or pulmonary nodules. Endometriosis presenting as hemorrhagic pleural effusion is rarely reported.

Objectives. The aim of the study was to describe pleural endometriosis presenting as hemorrhagic pleural effusion and to insist on the role of medical thoracoscopy in making the diagnosis with the help of a case report.

Methods. A case report of pleural endometriosis as a non-resolving hemorrhagic pleural effusion is presented.

Results. A 28-years old female on treatment for her primary infertility presented with non-resolving bloody pleural effusion and she was on empirical anti-tubercular drugs for the last four months. Medical thoracoscopy revealed flat brownish grey plaques over the diaphragmatic pleura and the histology of pleural tissue revealed pleural endometriosis. She was initiated on gonadotropin releasing hormone-leuprolide and there was some clinico-radiological improvement.

Conclusions. Thoracic endometriosis should be considered as one of the differentials for pleural effusion in female patient especially on treatment for infertility. Medical thoracoscopy should be the investigation of choice for evaluating pleural effusions before initiating empirical treatments.

KEYWORDS: pleural endometriosis; catamenial pleural effusion; thoracic endometriosis syndrome; hemorrhagic pleural effusion.

\section{Introduction}

Endometriosis is defined as presence of endometrial glands outside the uterine cavity and it most commonly involves the structures within the pelvic cavity. Thoracic endometriosis syndrome usually presents as pneumothorax, hemoptysis, hemothorax or pulmonary nodules. Pleural endometriosis is characterized by presence of functional endometrial tissue in the pleura [1]. Malignancy and tuberculosis are common causes of hemorrhagic pleural effusion. Endometriosis presenting as hemorrhagic pleural effusion are rarely reported [2]. Here we report a case of this rare entity in a 28-years old female.

\section{Case Report}

A 28-years old non-smoker female patient was referred to our department with moderate pleural collection after presenting to emergency department with cough and exertional breathlessness. Her cough was dry in nature and her effort tolerance was around 500 meters. There

\footnotetext{
*Corresponding Author: Dr. Akhil Paul, Department of Pulmonary Medicine, Christian Medical College and Hospital, Tamil Nadu, India. E- mail: akhil_pauli@yahoo.com
}

was no history of fever, chest pain, hemoptysis, loss of appetite and weight loss. The patient had significant past history, as she was being treated for her primary infertility for the last two years and has received multiple doses of clomiphene citrate.

As she failed in medical management, she was advised intrauterine insemination. During the work up for the above she was incidentally diagnosed to have right moderate pleural collection. Diagnostic thoracocentesis revealed straw colored exudative lymphocytic fluid, ultrasound guided pleural biopsy was done with Abram needle and the histopathology revealed lymphohistiocytic infiltrates. Based on the above results she was initiated on four antitubercular drugs of rifampicin, isoniazid, ethambutol and pyrazinamide according to body weight.

She attained menarche at the age of seventeen and had dysmenorrhea in her each cycle, which lasts for 8-10 days. She had no past history of diabetes, hypertension, asthma or tuberculosis. There was no history suggestive of connective tissue disease. Patient was born from a non-consanguineous marriage; both 
her parents and siblings were healthy. Her general examination, cardiovascular, abdominal and neurological system examinations were unremarkable. Respiratory examination revealed reduced chest expansion, stony dull note and reduced breath sounds in right mammary, interscapular and infrascapular areas.

Her blood investigations revealed hemoglobin of $12.8 \mathrm{gm} / \mathrm{dL}$, platelets of $2,86,000 / \mu \mathrm{L}$ and total leukocyte count $8,500 / \mu \mathrm{L}$ with differentials (neutrophil $62 \%$, lymphocyte $37 \%$, and eosinophils $1 \%$ ). She had normal renal and liver function (protein and albumin 6.4 and $4.5 \mathrm{~g} / \mathrm{dL}$ respectively) tests. Her sputum smears were negative for acid fast bacilli. Underlying connective tissue and vasculitis were ruled out by appropriate investigations. Admission chest $X$ ray showed moderate pleural effusion on the right side and computed tomography revealed normal lung parenchyma with moderate pleural effusion on the right side.

Diagnostic thoracocentesis revealed hemorrhagic lymphocytic exudative pleural effusion (total cell count: $480 / \mu \mathrm{L}$ mainly lymphocytic [78\%]); proteins: $4.5 \mathrm{~g} / \mathrm{dL}$; glucose: $107 \mathrm{mg} / \mathrm{dL}$; LDH: $455 \mathrm{IU} / \mathrm{L}$; adenosine deaminase: $18.6 \mathrm{U} / \mathrm{L}$ ). Pleural fluid gram stain, tubercular cultures were sterile and cytological examination was negative for malignant cells. Bronchcoscopy done ruled out endobronchial lesions. Medical thoracoscopy revealed normal visceral pleura, minimal adhesions in the posterior costophrenic recess and flat brownish gray plaques with hematoma were noticed in parietal pleura (Fig. 1).

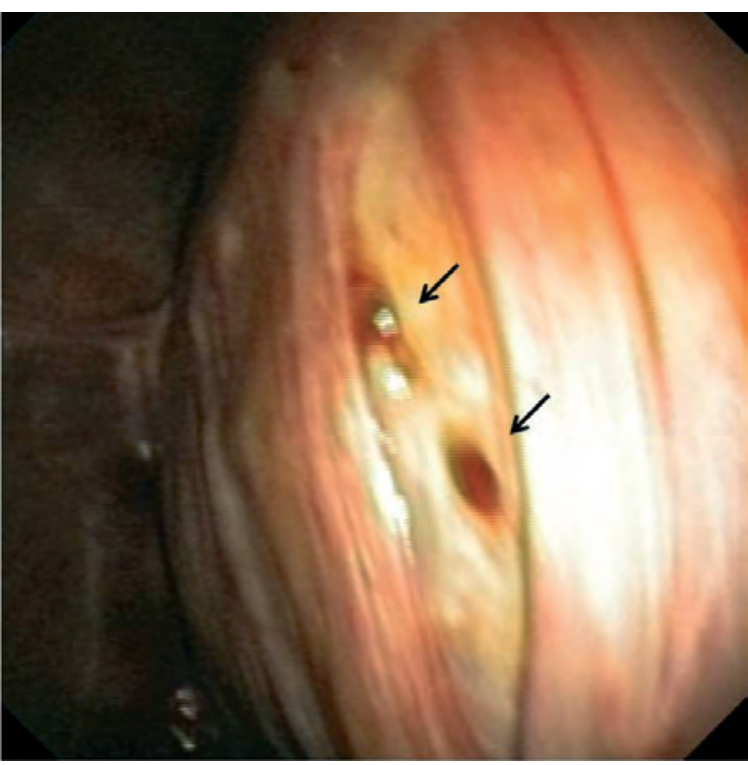

Fig. 1. Medical thoracoscopy revealing flat brownish gray plaques (black arrows) with hematoma over diaphragmatic pleura.
Biopsies were obtained from parietal and diaphragmatic pleura and they revealed fragments of endometrial glands lined by columnar cells surrounded by endometrial stroma along with hemosiderin-laden macrophages (Fig. 2).

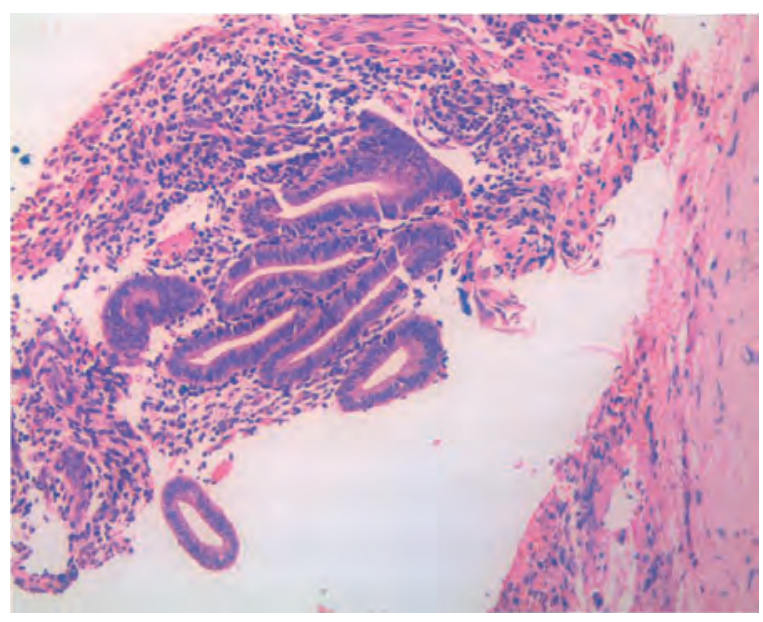

Fig. 2. Microphotograph of the biopsy specimen showing foci of endometrial glands surrounded by endometrial stroma. $(H \& E \times 20)$.

The pleural tissue stained positive for estrogen receptor and CD 10 immunostains (Fig. 3).

As the patient presented with pleural effusion the possible etiology considered was for:

- Tuberculosis;

- Malignancy;

- Secondary to connective tissue disease;

- Ovarian hyperstimulation syndrome secondary to clomiphene.

Tuberculosis and malignancy were ruled out by histopathology of pleural tissue obtained by medical thoracoscopy. Similarly, ovarian hyperstimulation was ruled out clinically by absence of features like weight gain, abdominal pain, vomiting, ascites and bilateral pleural effusion. Connective tissue disease was ruled out by absence of symptoms, clinical features and serology. Patient was diagnosed to have pleural endometriosis and was started on leuprolide (gonadotropin releasing hormonal analogue) after getting expert opinion from gynecologist. Post second day lung thoracoscopy showed adequate expansion and intercostal drainage was removed. She was discharged on leuprolide with the advice to review after three months. The patient and her family were educated about the nature of disease; treatment options and the need of regular follow up. After three months on follow up the patient showed good clinical and radiological improvement. 


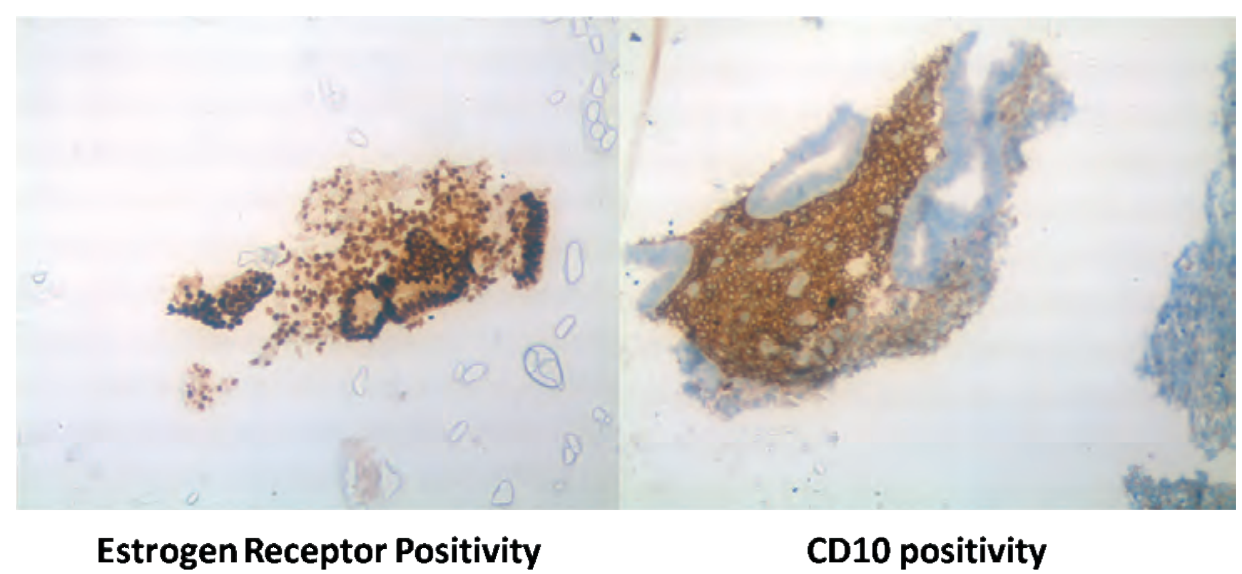

Fig. 3. Immunohistochemical analysis demonstrating positive staining estrogenic receptor and CD 10 stains (Original magnification $\times 20 \times$ digital magnification).

\section{Discussion}

Maurer in 1958 for the first time described thoracic endometriosis; it is associated with growth of endometrial tissue in the bronchial tree, lung parenchyma and pleura [1, 3]. Thoracic endometriosis is a rare uncommon entity and usually it affects right hemi-thorax [3] in $92 \%$ and left in $5 \%$ of cases. Pleural cavity is involved more commonly than lung parenchyma. The disease usually affects nulliparous women in their child bearing ages with a peak incidence between 20-30 years of age. The common presentations of thoracic endometriosis syndrome (TES) are pneumothorax $(70 \%)$, hemothorax $(12 \%)$, hemoptysis $(7 \%)$ and lung nodules (6\%) [4]. Chest pain, hemoptysis and breathing difficulty are common clinical manifestations of TES and symptoms typically present in 48-72 hours after start of menstruation.

The exact etiopathogenesis of TES is unknown, but many hypotheses have been suggested for presence of endometrial tissue in the thoracic cavity. Pleural TES is explained by Ivanoff's metaplasia theory (local metaplasia of cholemic epithelium) and Sampson's retrograde menstruation theory (trans diaphragmatic pass of endometrial tissue and implantation in thoracic cavity). Hematogenous migration of endometrial tissue via vascular and lymphatic micro embolization after gynaecological procedures like caesarean and curettage have been suggested as causes for parenchymal TES (hematogenous migration theory/microembolization theory) [1].

TES is diagnosed clinically based on presence of symptoms during menstruation $[1,5]$. Histopathological confirmation is needed for definitive diagnosis. Thoracoscopy is increa- singly used as the diagnostic modality for obtaining tissue for histology. As in our case, pleural and diaphragmatic implants can be seen in thoracoscopy and to increase the yield it is better to perform the procedure during the menstruation [6]. Medical treatment of TES includes hormonal manipulation and it involves suppression of ectopic endometrium with oral contraceptive pills, danazol, progestins and gonadotropin releasing hormonal analogues [7]. Surgical intervention is reserved of patients in whom the disease recurs after hormonal therapy. Pleurodesis and tissue resection are the treatment modalities surgically performed [7].

\section{Conclusion}

Pleural endometriosis and ovarian hyper stimulation syndrome should be among the differentials for pleural effusion especially in females on infertility treatment. Medical thoracoscopy should be considered as the investigation of choice for evaluating pleural effusions before initiating on empirical treatments.

\section{Conflict of Interests}

The authors declare no conflict of interest.

\section{Funding}

This research received no external funding.

\section{Acknowledgements}

The Departments of Pulmonary Medicine and Pathology of Christian Medical College, Vellore, where the study was done.

\section{Author's Contributions}

Saheer S, Akhil Paul, Prince James - formal analysis, investigation, methodology; Saheer $S$, Akhil Paul - drafting and manuscript revision; Rayani Palak - investigation. 


\section{ПЛЕВРАЛЬНИЙ ЕНДОМЕТРІОЗ: ГЕМОРАГІЧНИЙ ПЛЕВРАЛЬНИЙ ВИПІТ У 28-РІЧНОЇ ЖІНКИ 3 ПЕРВИННОЮ БЕЗПЛІДНІСТЮ (КЛІНІЧНИЙ ВИПАДОК)}

S. Saheer, A. Paul, P. James, R. Palak

CHRISTIAN MEDICAL COLLEGE AND HOSPITAL, TAMIL NADU, INDIA

Вступ. Ендометріоз характеризується наявністю ендометрію поза порожниною матки і зазвичай він виявляється в органах малого тазу. Ектрагенітальна його форма - ендометріоз легень - зазвичай маніфестує у вигляді пневмотораксу, кровохаркання, гемотораксу або легеневих вузликів. Вкрай рідко зустрічаються повідомлення про ендометріоз легень з клінічними проявами геморагічного плеврального вunomy.

Мета. Метою дослідження було описати ендометріоз легень, що маніфестував як геморагічний плевральний випіт та показати важливість медичної торакоскопії у постановці діагнозу.

Методи. Описано клінічний випадок рідкісної форми ендометріозу легень - геморагічного плеврального випоту, який не розсмоктувався.

Результати. Представлено клінічний випадок 28-річної жінки, яка лікувалася з приводу первинного безпліддя, з геморагічним плевральним випотом, який не розсмоктувався. Через підозру на туберкульоз протягом останніх чотирьох місяців вона приймала призначені лікарем чотири протитуберкульозних препарати. Медична торакоскопія виявила плоскі коричнево-сірі бляшки над діафрагмальною плеврою, а гістологія плевральної тканини виявила ендометріоз плеври. Пацієнтці було призначено лейпроліду ацетат (синтетичний агоніст гонадотропін-рилізинг гормону), після чого спостерігалося клінікорентгенологічне покращення.

Висновки. При проведенні диференціальної діагностики плеврального випоту у пацієнток, особливо при лікуванні безпліддя обов'язково слід розглядати ймовірність ендометріозу легень. Медична торакоскопія повинна бути методом вибору при оцінці плеврального випоту перед початком емпіричного лікування.

КЛЮЧОВІ СЛОВА: ендометріоз легень; катаменіальний плевральний випіт; геморагічний плевральний випіт.

Information about the authors

Dr Saheer S, Assistant Professor, Department of Pulmonary Medicine, Christian Medical College and Hospital, Tamil Nadu, India

ORCID 0000-0002-4737-7812, e-mail: drssaheer@gmail.com

Dr Akhil Paul, Post-Graduate Student, Department of Pulmonary Medicine, Christian Medical College and Hospital, Tamil Nadu, India

ORCID 0000-0002-4938-0636, e-mail: akhil_pauli@yahoo.com

Dr Prince James, Professor, Department of Pulmonary Medicine, Christian Medical College and Hospital, Tamil Nadu, India

ORCID 0000-0002-7347-5723, e-mail: drprincej@gmail.com

Dr Rayani Palak, Assistant Professor, Department of Pathology, Christian Medical College and Hospital, Tamil Nadu, India

ORCID 0000-0002-2303-9106, e-mail: palak.raiyani@gmail.com

\section{References}

1. Alifano M, Trisolini R, Cancellieri A, Regnard JF. Thoracicendometriosis: current knowledge. Ann Thorac Surg. 2006; 81:761-9. 07.044

DOI: https://doi.org/10.1016/j.athoracsur.2005.

2. Sevinç S, Unsal S, Oztürk T et al. Thoracic endometriosis syndrome with bloody pleural effusion in a 28 year old woman. J Pak Med Assoc. 2013 Jan; 63:114-6.
3. Rived X, Sebastián F, Rodríguez JI et al. Endometriosispleural complicada. Neumotórax catamenial. Cir Esp. 2002; 67:114-5.

4. Joseph J, Sahn SA. Thoracic endometriosis syndrome: new observations from an analysis of 110 cases. J Med. 1996;100:164-70. 89454-5 
5. Channabasavaiah AD, Joseph JV. Thoracic endometriosis: revisiting the association between clinical presentation and thoracic pathology based on thoracoscopic findings in 110 patients. Medicine (Baltimore). 2010;89:183- 8.

DOI: https://doi.org/10.1097/MD.0b013e3181df67d5

6. Bagan P, Le Pimpec Barthes F, Assouad J et al. Catamenial pneumothorax: retrospective study of surgical treatment. Ann Thorac Surg. 2003;75:378- 81

DOI: https://doi.org/10.1016/S0003-4975(02) 04320-5
7. Alifano M, Jablonski C, Kadiri H et al. Catamenial and noncatamenial, endometriosis-related or nonendometriosis-related pneumothorax referred for surgery. Am J Respir Crit Care Med. 2007;176:1048- 53. $5870 \mathrm{C}$

DOI: https://doi.org/10.1164/rccm.200704-

Received 21 Nov 2020; revised 18 Dec 2020; accepted 22 Dec 2020.

This is open access article distributed under the Creative Commons Attribution License, which permits unrestricted use, distribution, and reproduction in any medium, provided the original work is properly cited. 